\title{
Canadian Institute of Forestry Brief to the Canadian Council of Forestry Ministers
}

The following is the text of a brief presented to the C.C.F.M. at the time of the National Forest Congress, April 1986.

\section{Pesticides for Forest Management - A New Technology Gap \\ Background}

In 1980, the Canadian Council of Resource and Environment Ministers (CCREM) endorsed a 35\% increase in the harvest levels from Canada's forests by the year 2000. In addition, several provinces set specific growth targets for forest renewal on harvested and burned forest areas. Strategic planning for industrial and economic growth has been based on the assumption that these harvesting and renewal targets will be met in both the short-term and longterm futures.

Three natural processes - wildfire, insect and disease pests, and weed competition - kill trees and seriously suppress growth, thereby jeopardizing our ability to achieve wood supply targets and provide the fibre needed by the industry. Losses due to fire are controlled through the application of the most modern technology, including remote sensing, communications, aircraft, and chemical fire retardants. Losses caused by insects, diseases and competing vegetation could also be controlled in a highly cost-effective manner with pesticides, if they were made available to the forestry sector. At this time, pesticides are the only practical technology which would be used to control forest pest losses. However the serious delay in developing and registering pesticides, particularly herbicides, combined with localized public opposition to pesticide use in forestry is denying the forestry sector a highly cost-effective technology and jeopardizing its ability to compete internationally. The reality is that the forestry sector has set production and renewal targets which it does not have the technology to achieve.

The seriousness of the situation was recognized in 1982 , when the CCREM established a Task Force on Pesticides for Forest Management, and directed the Task Force to expedite registration of several high priority pesticides. While the Task Force succeeded in improving the availability of several insecticides, only one herbicide was registered during the 3year term of the Task Force. Since the Task Force disbanded in 1984, attempts to develop and register two important herbicides (Garlon and Velpar) have been blocked.

The Canadian Institute of Forestry developed a policy statement on the "Use of Chemical Pesticides in Forestry" in 1983. In this document, the CIF "supports the responsible use of registered chemical pesticides in forestry practices". The $\mathrm{CIF}$ reiterates that, in most situations across Canada, chemical pesticides remain the only practical, and clearly the most cost-effective technology to control losses caused by pests.

\section{Issue}

The current process for developing, registering and regulating the use of forestry pesticides in Canada is highly counterproductive. It is characterized by a number of policies or stances by the chemical industry, and federal and provincial regulatory agencies which are inconsistent and contradictory. As well, public opposition in several regions has led to decisions to cancel operational control programs which are essential to the achievement of forest production and renewal targets. More recently, opposition by government regulatory officials in British Columbia has resulted in the cancellation of two years of federally-approved herbicide research, with a loss of over one million dollars. This obstruction of essential research and operational programs which are designed to preserve our mature forests and tend our young growing forests, is denying a major sector of the Canadian economy the technology to do its job well and compete effectively, while providing no apparent benefit to Canadian society. This technology gap must be bridged if we are to achieve the forest management objectives we have set to sustain and nurture the forest industry in this country.

\section{Recommendations}

1. The CIF urges the Forestry Ministers to:

a) Develop a coordinated, clear policy statement on pesticide use in forest management. The public positions taken by previous federal Ministers in charge of forestry, as well as some provincial Forestry Ministers, opposing pesticide use in forestry, have left the Canadian public confused about the importance of this technology.

b) Undertake, in partnership with the forest industry, a unified national program to inform the public on the social and economic importance of forest management, and the range of activities that constitute sound forest management, including pesticide use. The goal should be to develop broad public support for the practices and technology that provide significant socioeconomic benefits through good forest management.

2. The CIF urges the Forestry Ministers to strongly support research to:

a) Develop alternatives to conventional chemical insecticides for the control of insect pests, with special attention to microbial agents, parasites and predators, and pheromonones.

b) Develop and register several new chemical herbicides which are critically needed to ensure forest renewal and protect our investments in regeneration.

c) Develop alternatives to herbicides for vegetation control.

d) Significantly improve our technical capability to aerially apply herbicides in a cost-effective manner.

3. The CIF urges the Forestry Ministers to consult immediately with the federal Ministers involved in pesticide registration and the provincial environment Ministers with the aim of resolving the impasses which:

a) Have prevented the field testing of the herbicide, Garlon, in British Columbia both in 1984 and 1985, with the loss of over one million dollars. Garlon is critically needed to replace 2,4,5-T which was lost to the forestry sector in 1985 . 
b) Have prevented the registration of Velpar for aerial application in forestry.

Both Velpar and Garlon have been registered for forestry use in the United States for some time.
4. The CIF recommends that the Forestry Ministers reallocate some of the financial support from programs to monitor the environmental/health impact of currently used forest insecticides to evaluation of the ecological effects of herbicide application in the forest environment

Canadian Institute of Forestry

April, 1986

\section{Bref présenté par l'Institut forestier du Canada au C.C.M.P.}

Le suivant est le texte du bref présenté au C.C.M.F. pendant le congrès forestier national en avril 1986.

\section{Les Pesticides en Aménagement forestier Un nouveau fossé technologique}

\section{Résumé}

En 1980, le Conseil Canadien des Ministres des Ressources et de l'Environnement (CCMRE) a approuvé une augmentation pour l'an 2000 de 35\% de l'exploitation forestière des forêts du Canada. De plus, quelques provinces ont prévu des niveaux spécifiques de croissance en terme de régenération forestiêre sur les sites forestiers exploités ou incendiés. Une planification stratégique pour une croissance industrielle et économique a été établie sur la prémisse que ces niveaux d'exploitation et de régénération seront atteints à court et long terme

Trois processus naturels- les feux de forêts, les insectes et les agents pathogènes, et la compétition des espèces indésirables, tuent les arbres et suppriment de façon marquante la croissance, et en conséquence remettent en question notre capacité à fixer des niveaux d'approvisionnement en matière ligneuse et à procurer à l'industrie le bois qui lui est nécessaire. Les pertes occasionnées par le feu sont contrôlées par l'application d'une technologie de pointe comprenant la télédétection, les communications, l'utilisation d'avions et d'inhibiteurs chimiques retardant le feu. Les pertes reliées aux insectes, aux maladies et à la compétition de la part de la végétation indésirable pourrait être aussi controlée de façon très économiquement efficace au moyens de pesticides, s'il était possible de les utiliser en foresterie. Présentement, les pesticides constituent la seul technologie pratique permettant de contrôler les pertes dûes aux insectes, aux maladies et à la compétition. Toutefois, de sérieux retards dans le développement et l'homologation des pesticides, en particulier pour les herbicides, en plus de l'opposition localisée du public en ce qui a trait à l'utilisation des pesticides en foresterie privent le secteur forestier d'une technologie très économiquement efficace et remettent en question sa capacité d'affronter la compétition internationale. La réalité est que le secteur forestier s'est fixé des niveaux de production et de régénération dont il n'a pas la technologie nécessaire pour atteindre.

L'état sérieux de la question a été reconnu en 1982 lorsque le CCMRE a mis sur pied un Groupe d'étude sur les pesticides en Aménagement forestier et a recommandé au Groupe d'étude d'homologuer le plus rapidement possible certains pesticides de grande importance. Même si le Groupe d'étude réussissait améliorer la disponbilité de certains insecticides, seulement un herbicide fut homologué au cours des trois années du mandat du Groupe d'étude. Depuis le démembrement du Groupe d'étude en 1984, les essais de développement et d'homologation de deux herbicides reconnus (Garlon et Velpar) ont échoué.
L'Institut Forestier du Canada a élaboré en 1983 une prise de position sur "l'Utilisation des Pesticides chimiques en Foresterie". Dans ce document, l'IFC "approuve l'utilisation reconnue des pesticides chimiques homologués lors de traitements forestiers". L'IFC souligne que, dans la plupart des cas au Canada, les pesticides chimiques demeurent la seule technologie utile et économiquement efficace pour controler les pertes occasionnées par les agents destructeurs.

\section{Les Faits}

Le processus actuel de développement, d'homologation et de réglementation de l'utilisation des pesticides en foresterie au Canada est grandement improductif. II est caractérisé par un grand nombre de politiques ou de positions prises par l'industrie chimique, et par les bureaux de réglementation du fédéral et des provinces et qui sont inconsistantes et contradictoires entre elles. De plus, l'opposition de la part du public dans quelques régions a mené à prendre la décision d'abandonner des programmes opérationnels de contrôle qui étaient essentiels pour atteindre des niveaux de production et de régénération forestières. Encore plus, récemment, l'opposition exercée par les responsables de la réglementation du gouvernement de la Colombie Britannique a résulté en l'abandon d'un projet de recherche de deux ans, approuvé par le gouvernement fédéral sur un herbicide, entrainant une perte de plus de un million de dollars. Cette opposition instituée contre la recherche de base et les programmes opérationnels congus pour protéger nos forêts à maturité et pour entretenir nos jeunes forêts en croissance, prive un important secteur de l'économie canadienne d'une technologie lui permettant de faire son travail et d'affronter efficacement la compétition, sans permettre de bénéfice apparent pour la société canadienne. Ce fossé technologique doit être comblé si nous voulons atteindre les objectifs d'amémagement forestier que nous avons élaborés pour maintenir et alimenter l'industrie canadienne.

\section{Recommandations}

1. L'IFC presse les Ministres des Forêts

a) De développer un énoncé de politique clair et coordonné sur l'utilisation des pesticides en aménagement forestier. Les prises de position publiques avancées par precédents Ministres fédéraux responsables des forêts ainsi que par quelques Ministres provinciaux, s'opposant l'utilisation des pesticides en foresterie, ont laissé le public canadien dans un état de confusion pour ce qui est de l'importance de cette technologie

b) D'entreprendre, en collaboration avec l'industrie forestière, un programme national commun d'information du public sur l'importance sociale et économique 